\title{
Meningkatkan Hasil Belajar Siswa Menggunakan Model Problem Based Learning Pada Mata Pelajaran IPA SMP
}

\author{
Asmah $^{1}$ \\ ${ }^{1}$ SMP Negeri 11 Kota Bima, Jl. Datuk Dibanta Kel. Jatibaru \\ Kec. Asakota Kota Bima, 84151 \\ Email: Asmah.kalampa@gmail.com
}

\begin{abstract}
Abstrak: Proses pembelajaran IPA menekankan pada pemberian pengalaman langsung untuk mengembangkan kompetensi agar menjelajahi dan memahami alam sekitar secara ilmiah untuk menumbuhkan kemampuan berpikir, bekerja dan bersikap ilmiah serta mengkomunikasikannya sebagai aspek penting kecakapan hidup. Untuk menjawab permasalahan pembelajaran IPA tersebut, diterapkan model pembelajaran berbasis masalah (Problem Based Learning) yang mengajak siswa untuk memahami persoalan secara kontekstual dan memecahkannya. Kemampuan pemecahan masalah ini diharapkan dapat meningkatkan hasil belajar siswa.Penelitian ini adalah penelitian tindakan kelas, yang bertujuan untuk untuk mengetahui apakah hasil belajar siswa akan meningkat setelah menggunakan model Problem Based Learning pada mata pelajaran IPA Kelas IXB SMP Negeri 11 Kota Bima. Analisis data menggunakan analisis deskriptif serta analisis kuantitatif atas tes hasil belajar. Penelitian ini dilaksanakan dalam 2 siklus. Hasil penelitian pada Siklus II, sebanyak 88\% siswa berhasil mencapai nilai KKM yaitu 70, hal ini menunjukkan bahwa penerapan model PBL dapat meningkatkan hasil belajar IPA.
\end{abstract}

Kata Kunci :Problem Based Learning, Hasil belajar, IPA.

\section{PENDAHULUAN}

Kurikulum 2013 merupakan upaya pemerintah meningkatkan kualitas pendidikan Indonesia di seluruh jenjang yang dinilai dari tiga ranah kompetensi, yaitu: pengetahuan, sikap, dan keterampilan. Kurikulum 2013 berfokus pada kegiatan aktif siswa melalui suatu proses ilmiah dengan tujuan agar pembelajaran tidak hanya menciptakan peserta didik yang mempunyai kompetensi pengetahuan saja, tetapi juga mampu menciptakan peserta didik yang baik dalam sikap dan terampil dalam mengaplikasikan ilmunya.
Kurikulum 2013 juga dikembangkan berbasis pada kompetensi yang sangat diperlukan sebagai instrumen untuk mengarahkan peserta didik menjadi: (1) manusia berkualitas yang mampu proaktif menjawab tantangan zaman yang selalu berubah; (2) manusia terdidik yang beriman dan bertakwa kepa Tuhan Yang Maha Esa, berakhlak mulia, sehat, berilmu,cakap, kreatif, mandiri; dan (3) warga negara yang demokratif dan bertanggung jawab (BSNP, 2006).

Sejalan dengan kurikulum 2013, proses pembelajaran IPA menekankan pada 
pemberian pengalaman langsung untuk mengembangkan kompetensi agar menjelajahi dan memahami alam sekitar secara ilmiah dan dilaksanakan secara inkuiri ilmiah (scientific inquiry) untuk menumbuhkan kemampuan berpikir, bekerja dan bersikap ilmiah serta mengkomunikasikannya sebagai aspek penting kecakapan hidup.

Dalam rangka mewujudkan tujuan pembelajaran IPA tersebut, maka perlu menumbuhkan keterampilan berpikir siswa terutama kemampuan pemecahan masalah sehingga penguasaan suatu konsep oleh siswa tidak hanya berupa hafalan dari sejumlah konsep yang telah dipelajarinya, tetapi mereka juga mampu menerapkan konsep yang dimilikinya pada aspek yang lain (Susilo, 2012).

Praktek nyata yang terjadi di dunia pendidikan Indonesia yang masih saja berkembang hingga saat ini adalah teacher oriented. Dimana sebagian besar aktivitas pembelajaran masih didominasi oleh guru. Proses belajar mengajar diawali dengan mencatat materi yang akan diajarkan di papan tulis kemudian guru menjelaskannya dengan metode ceramah dan tanya jawab. Pada saat proses tanya jawab berlangsung, mayoritas siswa cenderung pasif dan hanya siswa-siswa tertentu saja yang mau merespon pertanyaan guru. Selain itu tidak banyak siswa yang bertanya apalagi menyampaikan pendapatnya secara spontan. Hal ini merupakan indikasi bahwa mereka malas untuk berfikir sebagai ekses tidak terbiasa aktif dalam belajar dan terbiasa bergantung pada setiap materi yang disampaikan oleh guru.

Kalau masalah ini dibiarkan dan berlanjut terus, lulusan sebagai generasi penerus bangsa akan sulit bersaing dengan lulusan dari negara-negara lain. Lulusan yang diperlukan tidak sekedar yang mampu mengingat dan memahami informasi tetapi juga yang mampu menerapkannya secara kontekstual melalui beragam kompetensi. Di era pembangunan sekarang ini diperlukan pengetahuan dan keanekaragaman keterampilan agar siswa mampu memberdayakan dirinya untuk menemukan, menafsirkan, menilai dan menggunakan informasi, serta melahirkan gagasan kreatif untuk menentukan sikap dalam pengambilan keputusan.

Untuk mewujudkan hal itu, maka sekolah dan guru sebagai komponen utama pendidikan perlu mengelola pembelajaran sesuai dengan prinsip-prinsip kegiatan belajar mengajar antara lain: (1) kegiatan berpusat pada siswa, (2) belajar melalui berbuat, (3) belajar mandiri dan belajar bekerja sama sehingga pembelajaran diharapkan tidak terfokus pada guru, tetapi 
bagaimana cara mengaktifkan siswa dalam belajarnya (student active learning) (Muslich, 2007).

Untuk itu diperlukan suatu upaya untuk mengatasi keterbatasan pembelajaran IPA yang selama ini diterapkan yaitu dengan mengimplementasikan model pembelajaran berbasis masalah atau Problem Based Learning (PBL). Model pembelajaran PBL yaitu suatu inovasi pembelajaran yang dirancang untuk membantu peserta didik memahami teori secara mendalam melalui partisipasi peserta didik dalam kegiatan belajar mengajar dengan belajar untuk menyelesaikan masalah.Karakteristik utama dari PBL ini adalah sajian bahan ajar yang berupa masalah, disiapkan untuk memicu dan memacu terjadinya interaksi multiarah antarkomunitas di kelas sehingga tercipta iklim belajar dan mengajar yang kondusif. (Herman, 2017).

Pembelajaran berbasis masalah dimulai dari masalah yang autentik/seharihari dari kehidupan nyata dan bermakna. Tujuan utamanya adalah untuk meningkatkan penerapan pengetahuan, pemecahan masalah, dan keterampilan pembelajaran mandiri siswa yang mengharuskan mereka untuk secara aktif mengartikulasikan, memahami, dan memecahkan masalah. PBL terfokus, dimana pelajar mulai belajar dengan membahas simulasi dari suatu masalah otentik. PBL juga terpusat pada siswa, memerlukan pelajar untuk mengarahkan diri dalam pembelajaran mereka serta menentukan apa yang mereka pecahkan dari masalah yang dihadapi (Jonassen, 2008).

Lebih lanjut Ngalimun

menjelaskan PBL adalah suatu model pembelajaran yang melibatkan siswa untuk memecahkan suatu masalah melalui tahaptahap metode ilmiah sehingga siswa dapat mempelajari pengetahuan yang berhubungan dengan masalah tersebut dan sekaligus memiliki keterampilan untuk memecahkan masalah.

Dalam pelaksanaannya model PBL dapat membaca (mengamati), timbul pertanyaan (menanya), mengumpulkan data atau informasi (mengumpulkan data), menghubungkan peristiwa-peristiwa (mengasosiasi) dan menyampaikan hasil analisis tersebut (mengomunikasikan) baik dalam bentuk verbal dan tulisan. Model pembelajaran ini dapat menjadi program pendidikan yang mendorong kompetensi, belajar penuh makna, dan selanjutnya mendorong peserta didik agar berani untuk memberikan tanggapan-tanggapan terhadap pembelajaran IPA yang telah terjadi pada dunia nyata atau kontekstual, sehingga proses pembelajaran terpusat pada siswa (student centered). 
Pada akhirnya, dengan menggunakan model PBL ini diharapkan terjadinya peningkatan hasil belajar siswa dari aspek kognitif, tanpa melupakan aspek afektif dan keterampilan. Jihad dan Haris (2012) menyatakan bahwa hasil belajar yang dicapai oleh siswa sangat erat kaitannya dengan rumusan tujuan instruksional yang direncanakan guru sebelumnya yang dikelompokkan ke dalam tiga kategori, yakni domain kognitif, afektif, dan psikomotor.

Berdasarkan permasalahan tersebut di atas, peneliti akan melakukan pembelajaran yang inovatif dalam bentuk penelitian tindakan kelas yang diberi judul "Meningkatkan Hasil Belajar Siswa Menggunakan Model Problem Based Learning pada Mata Pelajaran IPA kelas IXB SMP Negeri 11 Kota Bima”.

\section{METODE}

Jenis penelitian ini adalah penelitian tindakan kelas.Penelitian ini dilaksanakan pada bulan Januari sampai dengan Februari 2019 di Kota Bima. Subyek penelitian adalah siswa kelas IX-B SMP Negeri 11 Kota Bima yang berjumlah 25 siswa.Instrumen penelitian yang digunakan adalah lembar observasi dan lembar penilaian hasil belajar.Pengumpulan data menggunakan teknik observasi dan dokumentasi.Sedangkan analisis data yang digunakan adalah analisis deskriptif dan analisis kuantitatif tes hasil belajar.

\section{HASIL DAN PEMBAHASAN}

\section{Siklus I}

Pada tahap perencanaan, peneliti melakukan kegiatan diantaranya membuat silabus, RPP, lembar tes dan lembar observasi.Pada tahap tindakan, peneliti melakukan kegiatan pembelajaran menggunakan RPP yang telah disusun dan menggunakan model pembelajaran Problem Based Learning.Tahap tindakan dilaksanakan dalam 2 pertemuan.Sedangkan pada tahap observasi, peneliti dibantu oleh observer untuk memantau kegiatan pembelajaran.

Berikut hasil tes formatif siklus I yang dilaksanakan pada akhir pertemuan.

Tabel 1. Hasil Tes Formatif Siklus I

\begin{tabular}{|c|c|c|c|}
\hline Nilai & $\begin{array}{c}\text { Frekuensi } \\
\text { Jumlah } \\
\text { siswa }\end{array}$ & Prosentase & Keterangan \\
\hline 90 & 2 & $8 \%$ & KKM \\
\hline 80 & 4 & $16 \%$ & KKM \\
\hline 70 & 3 & $12 \%$ & KKM \\
\hline 60 & 7 & $28 \%$ & Belum KKM \\
\hline 50 & 5 & $20 \%$ & Belum KKM \\
\hline 40 & 1 & $4 \%$ & Belum KKM \\
\hline 0 & 3 & $12 \%$ & Tidak hadir \\
\hline Jumlah & 25 & $100 \%$ & \\
\hline
\end{tabular}

Berdasarkan tabel 1 di atas terdapat 2 orang siswa yang mendapat nilai 90 dengan persentase sebesar $8 \%$, ada 4 orang siswa atau sebesar $16 \%$ yang mendapat nilai 80 , dan sebanyak 3 orang atau $12 \%$ siswa yang mendapat nilai 70 . Total siswa yang berhasil 
mencapai nilai KKM adalah sebanyak 9 orang atau sebesar $36 \%$. Selanjutnya terdapat 7 siswa yang mendapat nilai 60 atau sebesar $28 \%$, lalu ada 5 orang yang mendapat nilai 50 atau sebesar $20 \%$, kemudian 1 orang yang mendapat nilai 40 atau sebesar $4 \%$. Untuk siswa 3 orang yang tidak hadir peneliti memberikan nilai 0 (nol) pada ketiga orang tersebut. Hal ini berarti masih ada 16 orang yang belum mampu mencapai nilai KKM atau sebesar $64 \%$.

Berdasarkan kegiatan pelaksanaaan dan observasi, langkah berikutnya adalah melakukan refleksi. Pada tahap ini dilakukan pengkajian terhadap kegiatan yang telah dilaksanakan, terutama yang hasilnya belum optimal atau masih kurang akan dilakukan perbaikan pada siklus berikutnya.

Dari data-data yang telah diperoleh dapat dijelskan sebagai berikut :

1) Masih ada sebagian siswa yang belum dapat mengikuti kegiatan pembelajaran IPA dengan model problem based learning secara efektif karena masih belum fokus dan terlihat bergurau.Sehingga masih terlihat siswa yang belum dapat menyampaikan pendapat dalam diskusi kelompok dengan baik. Begitu pula ketika mengerjakan lembar aktivitas siswa sehingga masih kesulitan dalam mengalisis sesuai dengan kompetensi dasar harus dicapai.
2) Dari sudut pandang kegiatan pembelajaran yang dilakukan oleh guru masih ada yang harus diperbaiki yaitu ketrampilan guru dalam mengaplikasikan model problem based learning pada pembelajaran IPA di kelas IX-B.

3) Hasil yang diperoleh pada siklus I ini sementara ini bahwa pelaksanaan KBM dan aktivitas siswa pada pembelajaran IPA dengan model problem based learning belum optimal sehingga harus diperbaiki pada siklus II.

Setelah melakukan diskusi dengan observer pada tahap refleksi, peneliti memutuskan untuk melanjutkan penelitian ke siklus II karena pada siklus I indikator keberhasilan penelitian belum tercapai yaitu sebanyak $80 \%$ mencapai nilai KKM sebesar 70.

\section{Siklus II}

Pada tahap perencanaan, peneliti melakukan kegiatan diantaranya membuat silabus dan RPP perbaikan dari siklus I, lembar tes dan lembar observasi.Pada tahap tindakan, peneliti melakukan kegiatan pembelajaran menggunakan RPP yang telah direvisi dan menggunakan model pembelajaran Problem Based Learning.Tahap tindakan dilaksanakan dalam 2 pertemuan.Sedangkan pada tahap 
observasi, peneliti dibantu oleh observer untuk memantau kegiatan pembelajaran.

Berikut hasil tes formatif siklus II yang dilaksanakan pada akhir pertemuan.

Tabel 2. Hasil Tes Formatif Siklus II

\begin{tabular}{|c|c|c|c|}
\hline Nilai & $\begin{array}{c}\text { Frekuensi } \\
\text { Jumlah } \\
\text { siswa }\end{array}$ & Prosentase & Keterangan \\
\hline 100 & 2 & $8 \%$ & KKM \\
\hline 90 & 5 & $20 \%$ & KKM \\
\hline 80 & 7 & $28 \%$ & KKM \\
\hline 70 & 8 & $32 \%$ & KKM \\
\hline 60 & 1 & $4 \%$ & Belum KKM \\
\hline 50 & 1 & $4 \%$ & Belum KKM \\
\hline 0 & 1 & $4 \%$ & Tidak hadir \\
\hline Jumlah & 25 & $100 \%$ & \\
\hline
\end{tabular}

Berdasarkan tabel 2 di atas terdapat 2 orang siswa yang mendapat nilai 100 dengan persentase sebesar $8 \%$, ada 5 orang siswa atau sebesar $20 \%$ yang mendapat nilai 90 , dan sebanyak 7 orang atau $28 \%$ siswa yang mendapat nilai 80 , kemudian ada 8 orang yang mendapat nilai 70 atau sebesar $32 \%$. Total siswa yang berhasil mencapai nilai KKM adalah sebanyak 22 orang atau sebesar $88 \%$. Selanjutnya terdapat 1 siswa yang mendapat nilai 60 atau sebesar $4 \%$, lalu ada 1 orang yang mendapat nilai 50 atau sebesar $4 \%$, dan 1 orang yang mendapat nilai 0 (nol) karena tidak hadir dengan alasan sakit. Hal ini berarti ada 3 orang yang belum mampu mencapai nilai KKM atau sebesar $12 \%$.

Selain itu berdasarkan hasil observasi ditemukan hal-hal sebagai berikut:
1) Berdasarkan hasil tes formatif II tingkat pemahaman siswameningkat pada siklus ke-2. Keseluruhan siswa yang mencapai nilai KKM sebesar 70 adalah $88 \%$. Hal ini menunjukkan penerapan pembelajaran IPA dengan model problem based learning hasilnya baik sehingga dapat meningkatkan hasil belajar siswa.

2) Dari sudut pandang kegiatan pembelajaran yang dilakukan oleh guru sudah menunjukkan perbaikan pembelajaran. Hal ini terbukti bahwa siswa sudah mulai menunjukkan konsentrasi pada pembelajaran model problem based learning.

3) Karena indikator keberhasilan sudah dicapai maka tidak perlu lagi diadakan siklus berikutnya.

Berdasarkan hasil pada tes tersebut terdapat $88 \%$ siswa telah memenuhi KKM atau telah memenuhi indikator keberhasilan dalam penelitian tindakan kelas yaitu minimal $80 \%$ siswa memperoleh nilai KKM sebesar 70 sehingga tidak perlu melanjutkan penelitian ke siklus berikutnya.

Berdasarkan hasil pada siklus I dan siklus II, dapat dikatakan bahwa penerapan PBL dapat meningkatkan hasil belajar siswa.Hal ini sesuai dengan hasil penelitian Perdana dan Slameto (2018) bahwa penerapan model pembelajaran Problem Based Learning dapat meningkatkan hasil 
belajar.Bila menggunakan bantuan media pembelajaran, maka tingkat keberhasilan tersebut semakin besar.

Peningkatan hasil belajar IPA yang diperoleh ini juga di dukung oleh pendapat Amir (2009) yang menjelaskan bahwa PBL ini mempersiapkan siswa untuk berpikir kritis dan analitis, dan untuk mencari serta menggunakan sumber pembelajaran yang sesuai.Demikian juga dengan hasil analisis data dan pembahasan pada penelitian Rahmasari (2016)yang menyimpulkan bahwa penggunaan model pembelajaran PBL dapat meningkatkan hasil belajar siswa pada umumnya.Setelah diberikan tindakan dengan menerapkan model pembelajaran PBL pada mata pelajaran IPA, terdapat peningkatan nilai rata-rata hasil belajar.

\section{KESIMPULAN}

Tes hasil belajar pada siklus II diperoleh bahwa terdapat $88 \%$ siswa yang memperoleh nilai KKM sebesar 70. Sehingga penerapan ModelProblem Based Learning pada materi IPA telah berhasil meningkatkan hasil belajar siswa kelas IX-B SMP Negeri 11 Kota Bima tahun pelajaran 2018-2019.

\section{DAFTAR PUSTAKA}

Amir, M Taufiq (2009). Inovasi Pendidikan Melalui Problem Based Learning. Jakarta: Prenada Media Group.
BSNP. (2006). Panduan Pengembangan Kurikulum. Jakarta: Badan Standar Nasional Pendidikan.

Herman, Tatang. (2007). Pembelajaran Berbasis Masalah untuk Meningkatkan Kemampuan Berpikir Matematis Tingkat Tinggi Siswa Sekolah Menengah Pertama.Educationist No.1 Vol. 1 Januari 2017.Disunting tanggal 5 Februari 2019 dari google scholar.

Jihad, Asep., Haris, Abdul. (2012). Evaluasi Pembelajaran. Yogyakarta: Multi Pressindo.

Jonasen, D.H. and Woei Hung. (2008). All Problems are not Equal: Implications for Problem-Based Learning. The Interdisciplinary Journal of Problembased Learning, 2 (2) : 6 - 28. Disunting tanggal 19 Januari 2019 dari google scholar.

Muslich. (2007). KTSP Pembelajaran Berbasis Kompetensi dan Kontekstual. Jakarta: Bumi Aksara.

Ngalimun. (2014). Strategi dan Model Pembelajaran.Yogyakarta: Aswaja Pressindo.

Perdana, Surya Ariz., Slameto. (2018). Penggunaan Metode Problem Based Learning. Jurnal Pendidikan Dasar, Volume 4, Nomor 2, hlm. 73 78.Disunting tanggal 7 Januari 2019 dari google scholar.

Rahmasari, Riana. (2016). Penerapan Model Pembelajaran Problem Based Learning untuk Meningkatkan Hasil Belajar IPA Kelas V SD. Jurnal Pendidikan Guru Sekolah Dasar.Edisi 36 tahun ke-5 Tahun 2016.Disunting pada tanggal 20 Januari 2019 dari google scholar. 
Susilo, A.B. (2012). Pengembangan Model Pembelajaran IPA Berbasis Masalah untuk Meningkatkan Motivasi Belajar dan Berpikir Kritis Siswa SMP.Journal of Primary Educational.No. 1 Vol. 1 Tahun 2012.Disunting tanggal 7 Januari 2019 dari google scholar. 